\title{
RECORD OF A LATE JURASSIC DEEP-WATER CANYON AT CHISIK ISLAND, SOUTH-CENTRAL ALASKA: FURTHER DELINEATION OF NAKNEK FORMATION DEPOSITIONAL SYSTEMS IN LOWER COOK INLET
}

Trystan M. Herriott ${ }^{1}$, Marwan A. Wartes ${ }^{1}$, and Paul L. Decker ${ }^{2}$

INTRODUCTION

Sedimentologic, stratigraphic, and geologic mapping-based studies of the Upper Jurassic Naknek Formation are part of a Department of Natural Resources-led project to examine the Mesozoic stratigraphy and structure of lower Cook Inlet (Gillis, 2013, 2014; Wartes, 2015; Herriott, 2016 [this volume]). This ongoing research aims to elucidate geologic relations that are relevant to the petroleum systems in the Cook Inlet forearc basin, a producing yet underexplored hydrocarbon province (LePain and others, 2013). Our recent Naknek Formation work focuses on an $\sim 80 \mathrm{~km}$ trend exposed parallel to the basin margin between Iniskin and Tuxedni bays (fig. 6-1), building on the geologic framework established by Detterman and Hartsock (1966).

In this brief paper, we continue to document stratigraphic relations between the Snug Harbor Siltstone and Pomeroy Arkose Members (Naknek Formation), which are interpreted chiefly as marine slope and base-of-slope/basin floor units, respectively (LePain and others, 2013; Wartes and others, 2013). The Snug Harbor-Pomeroy contact is typically sharp and conformable and is mapped at the base of amalgamated, tabular packages of light-gray-weathering arkose (Detterman and Hartsock, 1966; Herriott and Wartes, 2014). However, during field investigations in 2013 and 2014, atypical stacking relations between the Snug Harbor and Pomeroy were recognized in the Mount Pomeroy and Hickerson Lake areas (fig. 6-1), where lithofacies, stratal geometries, and seismic-scale stratigraphic architecture were interpreted to record processes associated with two deep-water canyons (Herriott and others, 2015a, 2015b). Presented below are new field observations from Chisik Island (fig. 6-1) that suggest establishment and filling of a third canyon in the Snug Harbor-Pomeroy interval, further delineating the stratigraphic framework of Cook Inlet during the Late Jurassic.

\section{STRATIGRAPHIC OBSERVATIONS AT CHISIK ISLAND}

Aerial reconnaissance of a superb mountainside exposure at the north end of Chisik Island revealed prominent concave-up erosional surfaces in the Snug Harbor-lower Pomeroy that are overlain by channel-form sediment bodies (fig. 6-2). A basal erosional surface is identified as the master channel margin. This surface cuts across $\sim 100 \mathrm{~m}$ of stratigraphy, marking the Snug Harbor-Pomeroy contact to the northeast, separating two architecturally distinct packages of Snug Harbor (the lower denoted here as $\mathrm{Jns}_{1}$ and the upper as $\mathrm{Jns}_{2}$ ) in the central area of figure 6-2, and juxtaposing the lower sandstone member (Naknek Formation) and $\mathrm{Jns}_{2}$ to the southwest, where $\mathrm{Jns}_{1}$ is entirely truncated. $\mathrm{Jns}_{1}$ comprises relatively thin, tabular beds of siltstone and very-fine-grained sandstone typical of Snug Harbor (Herriott and Wartes, 2014). Jns 2 is distinguished from $\mathrm{Jns}_{1}$ in that it lies within the master channel, hosts abundant channel-form stratal geometries, and is sandier. The contact between Snug Harbor and lower Pomeroy $\left(\mathrm{Jnp}_{1}\right)$ is mapped at the base of very thick successions of amalgamated arkoses that are tabular to locally channelized, although channel margins are less steep than those observed in $\mathrm{Jns}_{2}$ (fig. 6-2); siltstone intercalations in $\mathrm{Jnp}_{1}$ are only a minor constituent. Finally, an upper Pomeroy unit $\left(\mathrm{Jnp}_{2}\right)$ contains thicker amalgamated arkosic packages than are observed in $\mathrm{Jnp}_{1}$, is dominantly tabular-bedded at the scale of exposure, lacks siltstone interbeds, and is lithostratigraphically consistent with Pomeroy successions that typically crop out conformably above Snug Harbor of Jns $_{1}$ affinity (Herriott and Wartes, 2014).

\section{INTERPRETATIONS AND DISCUSSION}

The lithostratigraphic relations and large-scale stratal architecture described above and in figure 6-2 are interpreted as the record of a deep-water canyon. This Chisik Island canyon association consists of pre-, intra-, and beyond-canyon facies- $\mathrm{Jns}_{1}$, $\mathrm{Jns}_{2}-\mathrm{Jnp}{ }_{1}$, and $\mathrm{Jnp}_{2}$, respectively-permitting insights into trends in Naknek Formation deep-water depositional systems. Deposition of $\mathrm{Jns}_{1}$ (slope facies) was terminated by canyon incision and establishment of intra-canyon channel belts ( $\mathrm{Jns}_{2}$ ) with relatively steep channel margins during an early canyon-fill episode that was likely dominated by erosional processes and sediment bypass. Jnp ${ }_{1}$ marks a transition to widening channel belts with relatively gentle channel margins, increasing

\footnotetext{
${ }^{1}$ Alaska Division of Geological \& Geophysical Surveys, 3354 College Rd., Fairbanks, AK 99709-3707; trystan.herriott@alaska.gov

${ }^{2}$ Alaska Division of Oil and Gas, 550 W. 7th Ave., Suite 1100, Anchorage, AK 99501-3560
} 


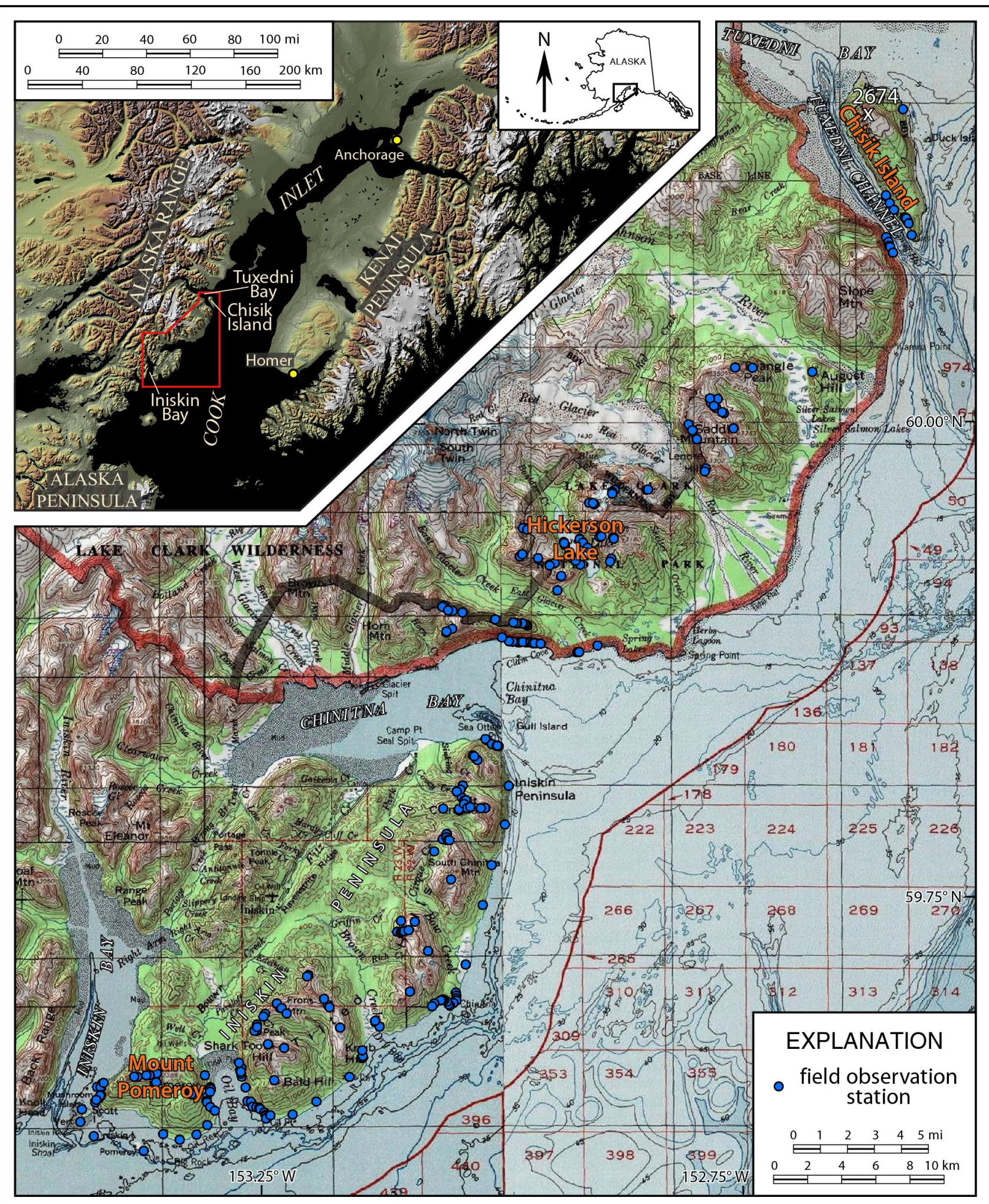

Figure 6-1. Location map of the Iniskin-Tuxedni bays study area. Detailed observations of the Naknek Formation were made by the authors at more than 325 localities during six field seasons. Evidence of deep-water canyon and associated processes in the Snug Harbor Siltstone-lower Pomeroy Arkose Members interval have been documented in three areas (see orange labels with black outlines and text for discussion). Topographic base map from portions of U.S. Geological Survey Iliamna, Seldovia, Lake Clark, and Kenai 1:250,000-scale quadrangles; shaded-relief image modified after U.S. Geological Survey Elevation Data Set Shaded Relief of Alaska poster (available for download at http://eros.usgs.gov/alaska-0). 

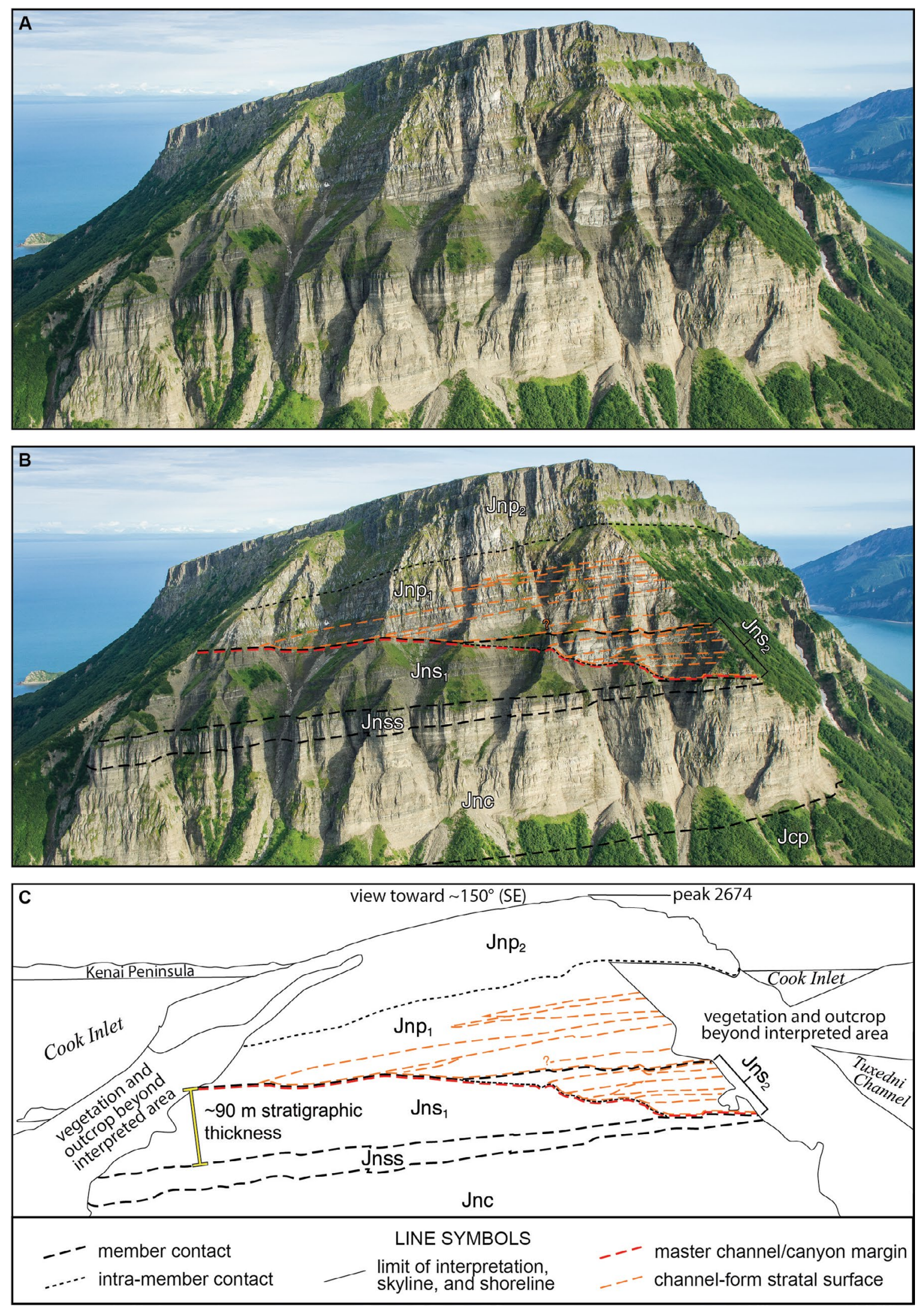

Figure 6-2. Oblique aerial view southeastward of the northern extent of Chisik Island (fig. 6-1). Key stratigraphic relations in the Snug Harbor Siltstone ( $\mathrm{Jns}_{1}$ and $\mathrm{Jns}_{2}$ ) and Pomeroy Arkose ( $\mathrm{Jnp}_{1}$ and $\mathrm{Jnp}_{2}$ ) Members are discussed in the text and include the distribution of lithofacies and stratigraphic architecture. A. Noninterpreted photograph. B. Photogeologic interpretation. C. Line drawing interpretation. Approximately $400 \mathrm{~m}$ ( 1,300 ft) of topographic relief lie between peak 2674 (fig. 6-1) and the base-of-cliff exposures of Chisik Conglomerate Member (Jnc; Naknek Formation), for sense of scale. Additional abbreviations: Jcp = Paveloff Siltstone Member, Chinitna Formation; Jnss = lower sandstone member, Naknek Formation; SE = southeast. Photograph by T.M. Herriott. 
occurrence of tabular beds, and increasing sandstone-to-siltstone ratios. These $\mathrm{Jns}_{2}$ to $\mathrm{Jnp}_{1}$ trends may in part reflect a reduction in gradient along the canyon axis and reduced bypass at this site, potentially as a result of canyon-associated depositional systems trending toward equilibrium grade as the base-of-slope environment accumulated sediment and the basin-floor depositional elements of the Pomeroy onlapped the inherited paleobathymetric profile of the Snug Harbor slope (Herriott and others, 2015a). Jnp ${ }_{2}$ is interpreted to record distributary lobe sedimentation beyond the canyon mouth, which retreated farther upslope as arkosic sediment continued to debouch onto the basin floor (compare with Mutti and Normark, 1987).

These observations and interpretations are consistent with: (1) our prior work (see references above), (2) the tendency of deep-water channelized depositional systems to evolve in space and time (for example, Posamentier and Kolla, 2003; Hubbard and others, 2014), with erosional processes and bypass dominant in steeper gradient settings and channelized-aggradational to distributary-aggradational processes dominant in lower gradient settings, and (3) deep-water canyons commonly serving as conduits to route coarse-grained sediment to basin floors (for example, Miall, 1990). The Chisik Island canyon-in conjunction with our observations in the Mount Pomeroy and Hickerson Lake areas - also establishes a maximum canyon spacing of $\sim 30-40 \mathrm{~km}$ along the Iniskin-Tuxedni bays outcrop belt (fig. 6-1). This study thus further constrains depositional systems evolution, sediment routing pathways, and location of paleobathymetric elements during Snug Harbor and Pomeroy deposition, yielding insights into the distribution of coarse-grained strata that may host oil and gas in Cook Inlet.

\section{ACKNOWLEDGMENTS}

Funding for this and related studies was provided primarily by the State of Alaska; geologic mapping was partially supported by the National Cooperative Geologic Mapping Program through STATEMAP under award numbers G13AC00157 and G15AC00199 (administered by the U.S. Geological Survey). Land access for the Naknek Formation work was generously permitted by Cook Inlet Region, Inc., and Chickaloon, Knik, Ninilchik, Salamatof, Seldovia, and Tyonek Native village corporations, as well as Lake Clark National Park \& Preserve. Pathfinder Aviation and helicopter pilot Merlin "Spanky" Handley safely transported our field crew during the 2015 field season. We thank the owners and staff of the former cannery on Chisik Island for their hospitality. This work benefited from numerous discussions with David LePain regarding the Naknek Formation and deep-water depositional systems; we also thank Dave for reviewing this paper.

\section{REFERENCES CITED}

Detterman, R.L., and Hartsock, J.K., 1966, Geology of the Iniskin-Tuxedni region, Alaska: U.S. Geological Survey Professional Paper 512, 78 p., 6 sheets, scale 1:63,360.

Gillis, R.J., ed., 2013, Overview of 2012 field studies - Upper Alaska Peninsula and west side of lower Cook Inlet, Alaska: Alaska Division of Geological \& Geophysical Surveys Preliminary Interpretive Report 2013-1, 48 p. doi:10.14509/24824

Gillis, R.J., ed., 2014, Cook Inlet program 2013 field studies-Observations and preliminary interpretations from new 1:63,360-scale geologic mapping of the Iniskin Peninsula, lower Cook Inlet, Alaska: Alaska Division of Geological \& Geophysical Surveys Preliminary Interpretive Report 2014-2, 31 p. doi:10.14509/27303

Herriott, T.M., ed., 2016 (this volume), Petroleum-related geologic studies in lower Cook Inlet during 2015, Iniskin-Tuxedni region, south-central Alaska: Alaska Division of Geological \& Geophysical Surveys Preliminary Interpretive Report 2016-1, 78 p. doi: $10.14509 / 29532$

Herriott, T.M., and Wartes, M.A., 2014, Geologic-mapping-based observations of the Middle Jurassic Chinitna Formation and Upper Jurassic Naknek Formation in the Tilted Hills, Iniskin Peninsula, Cook Inlet, Alaska: Alaska Division of Geological \& Geophysical Surveys Preliminary Interpretive Report 2014-3, 23 p. doi:10.14509/27305

Herriott, T.M., Decker, P.L., and Wartes, M.A., 2015a, Evidence of a submarine canyon in the Snug Harbor Siltstone and Pomeroy Arkose Members, Naknek Formation, south-central Alaska - Implications for the distribution of coarse-grained sediment in Upper Jurassic strata of Cook Inlet, in Wartes, M.A., ed., Energy-related studies during the 2014 field season, western Cook Inlet, Alaska: Alaska Division of Geological \& Geophysical Surveys Preliminary Interpretive Report 2015-5-9, p. 57-62. doi:10.14509/29464

Herriott, T.M., Wartes, M.A., and Decker, P.L., 2015b, Deep-water canyons in the Snug Harbor Siltstone and Pomeroy Arkose Members, Naknek Formation, Alaska-New insights into the sequence stratigraphy of the Late Jurassic Cook Inlet forearc basin [presentation]: Geological Society of America, Cordilleran Section Annual Meeting, May 11-13, 2015, Anchorage, Alaska: Alaska Division of Geological \& Geophysical Surveys, 37 p. doi: 10.14509/29443

Hubbard, S.M., Covault, J.A., Fildani, Andrea, and Romans, B.W., 2014, Sediment transfer and deposition in slope channels-Deciphering the record of enigmatic deep-sea processes from outcrop: Geological Society of America Bulletin, v. 126 , v. 5-6, p. 857-871. doi:10.1130/B30996.1 
LePain, D.L., Stanley, R.G., Helmold, K.P., and Shellenbaum, D.P., 2013, Geologic framework and petroleum systems of Cook Inlet basin, south-central Alaska, in Stone, D.M., and Hite, D.M., eds., Oil and Gas Fields of the Cook Inlet Basin: American Association of Petroleum Geologists Memoir 104, p. 37-116.

Miall, A.D., 1990, Principles of sedimentary basin analysis, second edition: New York, Springer-Verlag, 668 p.

Mutti, Emiliano, and Normark, W.R., 1987, Comparing examples of modern and ancient turidite systems_-Problems and concepts, in Leggett, J.K., and Zuffa, G.G., eds., Marine Clastic Sedimentology: London, Graham-Trotman, p. 1-38.

Posamentier, H.W., and Kolla, Venkatarathnan, 2003, Seismic geomorphology and stratigraphy of depositional elements in deep-water settings: Journal of Sedimentary Research, v. 73, no. 3, p. 367-388. doi:10.1306/111302730367

Wartes, M.A., ed., 2015, Energy-related studies during the 2014 field season, western Cook Inlet, Alaska: Alaska Division of Geological \& Geophysical Surveys Preliminary Interpretive Report 2015-5, 62 p. doi: $10.14509 / 29455$

Wartes, M.A., Herriott, T.M., Helmold, K.P., and Gillis, R.J., 2013, Preliminary stratigraphic interpretation of the Naknek Formation-Evidence for Late Jurassic activity on the Bruin Bay fault, Iniskin Peninsula, lower Cook Inlet, in Gillis, R.J., ed., Overview of 2012 field studies - Upper Alaska Peninsula and west side of lower Cook Inlet, Alaska: Alaska Division of Geological \& Geophysical Surveys Preliminary Interpretive Report 2013-1H, p. 39-46. doi:10.14509/24851 